\title{
Chesla C. Sherlock as First Editor of Better Homes and Gardens
}

\author{
C A R O L R E U S S.P.
}

A magazine is an idea in the beginning, Herbert R. Mayes has commented, and then a man. ${ }^{1}$ The idea for Better Homes and Gardens, founded in 1922 as Fruit, Garden and Home, was Edwin T. Meredith's, and his interest in it until his death in 1928 sparked those persons in his employ to build the magazine into an important service for American homemakers and an important property of the Des Moinesbased Meredith Corporation. A key man during those early years was Chesla C. Sherlock, first editor of the magazine.

Meredith had founded Successful Farming in 1902, and by 1922 he was ready to reach out to the growing number of middle-class Americans who were buying, building, and remodeling urban and suburban homes, especially those with property for landscaping and gardening. He planned a home magazine for a truly mass audience, estimating a circulation of 150,000 to start, with an increase to 500,000 by the end of the first year and $1,000,000$ by the end of the fourth year. ${ }^{2}$ Meredith's expectations were met, although the name of the magazine was changed to Better Homes and Gardens after two years.

Meredith did not have an editor assigned to the new magazine when he announced it in April, 1922. He and his Successful Farming staff prepared the preliminary issues and promotional materials because, as he told one job seeker in April, "at present we do not have our plans definitely formed, and will not wish to take on much expense until business opens up in the fall." 3 Before many weeks had passed, however, and with little fanfare, Meredith hired the man who would translate the inspiration for the home magazine into issues that readers

1 Herbert R. Mayes, "Herbert Mayes Takes a Look at Where Magazines Are and Where They Are Headed," Advertising Age (June 24, 1963), p. 102.

2 E. T. Meredith to Lafe Young, Jr., May 8, 1922, Meredith Papers, The University of Iowa Libraries, Iowa City.

3 E. T. Meredith to J. B. Kirbye, April 28, 1922, Meredith Papers. 
valued. 'The man was Chesla C. Sherlock, a native Iowan, then twenty-seven years old and an associate editor of the Iowa Homestead magazine. Sherlock had been impressed by E. T. Meredith for years, he admitted long after joining the firm. In 1913, when Sherlock was a student and Meredith was making a bid for the governorship of Iowa, Sherlock met his future publisher at a luncheon. Meredith's knack of conveying enthusiasm to his audience remained with Sherlock, who later wrote of Meredith that "he had that in him which, even then. caused one to believe in him." 4

Editor Sherlock's energy was boundless, and within days on the job he was suggesting ways to increase the value of the magazine to readers. He even recommended a series of booklets that could be prepared "in odd times outside of office hours" and distributed by the Subscribers Service Department. ${ }^{5}$ Sherlock was an imaginative, idealistic writer-editor-a resourceful catalyst determined to involve himself and his readers in the new magazine to keep it alive and profitable. In this respect he was a perfect match for E. T. Meredith, who had an uncanny ability to relate to readers' interests. Sherlock chafed if Successful Farming editor Allison Secor so much as। answered a printer's question about Fruit, Garden and Home if Sherlock happened to be out of the office.

Sherlock's share of the first issue of Fruit, Garden and Home was minimal because L. S. Goode, a long-time Successful Farming staff member, had the issue well under way before he was hired. The new editor was on the job long enough before the issue closed, however, to supply "Along The Garden Path With The Editor," a last-page conversation with readers that would become a long-time monthly column.

Even with an issue in hand the magazine was not easy to sell in 1922. R. R. Ring, Minneapolis advertising representative for the Meredith publications, told the publisher that advertisers were impressed with the early issues but not inclined to spend money on a new publication, adding, "We are featuring the fact that you are behind the publication and every advertiser will get his money's worth from the start."6

For almost five years Meredith's reputation and financial resources continued to support the new magazine. During the first eight months. Meredith admitted that the magazine had cost the company more

\footnotetext{
4 Chesla C. Sherlock, "Edwin T. Meredith: Being a Personality," unpublished manuscript, 1926, Meredith Papers.

5 Chesla C. Sherlock to E. T. Meredith, June 5, 1922, Meredith Papers.

6 R. R. Ring to E. T. Meredith, July 20, 1922, Meredith Papers.
} 
than $\$ 200,000$, not including the expenses of the Subscription Department. ${ }^{7}$ Not until 1927 did the new magazine bring a profit to Meredith's organization. $^{8}$

Reader interest was good from the beginning, however, and Sherlock's enthusiasm for the magazine increased as the early issues found acceptance among readers. "Our first goal," he wrote to Meredith in 1923, "must be to DOMINATE this field before anyone else has time and chance to beat us to it." $\mathrm{He}$ explained his plan to his publisher, saying:

We are in our most important period now; we are building up reader interest and enthusiasm; we want to keep on growing. To do that we must "sell" the reader on the idea that we are giving him 100 per cent service. This means, from a psychological standpoint, that we must prevent an actual or apparent packing of the contents from taking place. . .10

The ways to maintain reader loyalty, Sherlock explained, were reader service and more pages for editorial material. "Let us not start "milking' this cow," Sherlock wrote, "until she has her maturity. Then we can crowd her a little without running a risk of stunting her growth."11

Editor Sherlock, like his publisher, worked hard to involve readers in the magazine. His own penchant for sentimentality and idealism became evident in the magazine within a few issues. There developed a me-to-you attitude in Sherlock's writing and in his' editing of material supplied by others, a characteristic that complemented Meredith's original idea for the magazine and set the stage for continued empathy with readers. Readers of Sherlock's columns were often reminded to turn to specific articles they might have missed, or to write to tell the editor about some home or garden problem, achievement, or desire. For months, the major editorial portion of the magazine opened with an attractive, inspirational frontispiece. Sherlock established a readers' forum, "Among Ourselves," and wrote editorials on homey topics such as the ideal home, Christmas at home, and investing in family contentment. He bought articles that reflected happy, inspirational attitudes toward daily problems, at the same time showing readers practical solutions to homemaking and gardening problems. He tried to bring personalities into the articles he published, to establish a rapport between them and the readers. Sherlock's romanticism extended to a popular series of articles that he researched and wrote under the running title "Homes of Famous Americans." Mere-

7 E. T. Meredith to J. C. Billingslea, January 23, 1923, Meredith Papers.

8 Ken Hill to Carol Reuss, January 13, 1970.

9 Chesla C. Sherlock to E. T. Meredith, December 22, 1923, Meredith Papers.

10 Ibid.

11 Ibid. 
dith liked the series well enough to reprint the articles in two volumes which were sold, given as premiums for new subscriptions, and distributed to business associates.

In 1925, Sherlock crystallized the rationale of the magazine, by then renamed Better Homes and Gardens, as it had been evolving under his editorship. "We started with a definite ideal in mind," he told a group in Boston, "and, generally speaking, that was to do what we could to interest people in better homemaking." 12 He explained, "We had a definite field in mind and that was the homemakers living in houses in cities, towns and suburbs. In other words, we do not direct our appeal to any particular minority group; we had in mind the progressive home-lover, whatever his station in life, who was sincerely fired with the desire to make his home, and the quality of living going into that home, "better." "13 Better Homes and Gardens, reported Sherlock, was for the family in its joint interests, not for the man or the woman alone. "We wanted a family-minded publication, and where the interests of the members of the family were no longer a family proposition, we were perfectly content for the respective members of the family to go to publications catering to that specific personal interest."14 Threc appeals-fiction, fashion, and sex-were discounted from the beginning.

Ccrtain appeals were utilized by Better Homes and Gardens in the 1920s to give the magazine its family and home-centered slant, Sherlock explained. The first among them was the how-to-do-it appeal. "We actually show people how to succeed in their garden work . . . how to decorate the house ... select a new furnace or kitchen cabinet ... what kind of a house to build; how to build it; how to cook and preserve the bounty of garden and berry patch-in short, we touched them in their everyday problems at more points ... than any other magazine ever had before."15 The how-to-do-it material in Better Homes and Gardens, Sherlock maintained, was not only practical but it was also highly inspirational. "It gives you a more wholesome appreciation of home and home life."16

Sentiment, the editor said, was still another tool used by Better Homes and Gardens for the benefit of readers. "We seek . . . to strike the mystic chords of sentiment and awaken those who have become dulled to the value of home and its influence upon their lives; to

12 Chesla C. Sherlock, Better Homes and Gardens Editorial Ideals (Des Moines, Iowa: Meredith Publishing Co., 1925), p. 2.

13 Ibid.

14 Ibid., p. 4.

15 Ibid., p. 5.

16 Ibid. 
arouse those already sensing something of its wholesome appeal to greater effort and more determined will to succeed. ..."17

The permanent home was still another aim of Better Homes and Gardens under Sherlock's editorship. He explained:

\begin{abstract}
We seek to encourage the building of better homes-houses that will endure more than a year and a day-then, we seek to encourage families to settle down and live in them, to get their roots down deep into the soil, to preserve around them the background which their lives have painted. We wanted to bring families to say: "This spot is our home, and here we live!" rather than, "Well, we are not going to live here forever, and we hadn't better spend the money for this improvement or really settle down and live here, because we are going to move as soon as we can." 18
\end{abstract}

The intangible values of a permanent home were carried without dogmatism in Better Homes and Gardens' house-plan section under Sherlock's editorial direction. There, for the first time, readers were cncouraged to build their homes in "units," as Sherlock wrote, "starting out small, but starting out well-and increasing the house as the family or the purse warrants."19 House plans sold through the magazine cost readers two dollars a set.

The yard and everything in it, Sherlock often said, "puts a setting around the jewel, the home." Readers' letters indicated their agreement with this editorial philosophy espoused by both Sherlock and his publisher. An article on Sherlock's effort to construct a back yard lily pool resulted in more than 350 letters from readers describing their own lily pool projects, some with photographs enclosed.

By the end of 1925, Sherlock categorized and ranked the subjects included in Better Homes and Gardens. Flowers, gardens, landscaping, and fruit articles covered about one-third of the magazine's editorial pages the preceding year. "Inspirational homemaking," which included the articles in Sherlock's series, "Homes of Famous Americans," as well as such articles as "And Now We Have Our Home" and "The Delightful Vogue of House Naming," ranked second in total pages published. About twenty-eight per cent of the magazine's editorial pages was devoted to such articles. Approximately fourteen per cent of the editorial space was devoted to articles on building and construction subjects; seven per cent, foods and recipes; five per cent, home improvement; three per cent, needlework; two per cent, poultry (the 1920s saw many back yard chicken runs); and one per cent, housekeeping methods and devices. ${ }^{20}$

Sherlock was assisted by Gwendolyn Watts the first year, when is-

17 lbid., p. 6.

18 lbid.

19 Ibid.

20 Ibid., p. 29. 
sues averaged fewer than sixty pages; and when she resigned in 1923 to return to teaching, Genevieve Callahan agreed to divide her time between the two Meredith publications. She handled the dual assignment for three years. Then, because of the growth of Better Homes and Gardens and the increasing work load for it, she chose to be associate editor of that magazine, in charge of foods articles, although her name continued to be listed as household editor of Successful Farming. As Sherlock's work increased he hired an assistant, Lou Richardson, who functioned as a managing editor for Better Homes and Gardens.

Because the editorial staff was so small, Sherlock and his associates relied heavily on articles supplied by outside contributors, most of whom were specialists in specific subject areas and many of whom were university professors. Many Better Homes and Gardens authors also wrote regularly for Successful Farming and were consultants to the Subscribers Information Bureau, which annually answered thousands of questions submitted by readers.

For a little longer than five years Chesla C. Sherlock developed the editorial side of the magazine from E. T. Meredith's original idea and plans. He and his small staff worked diligently and effectively to identify with the readers in ways that made them feel that the magazine was really theirs-written to them and for them. Sometimes foods editor Genevieve Callahan even made trips to towns in nearby states to survey Better Homes and Gardens readers' interests and needs. Editor Sherlock insisted on running his show his way, however, and gradually his warm relationship with E. T. Meredith, the man he had admired and almost idolized, deteriorated. Early in 1927, Sherlock intimated to some of his regular contributors that he and the magazine were about to separate. In May he and Meredith had an encounter that ended with Sherlock's resignation. Then, when Meredith heard that Sherlock had disclosed their differences to persons outside the company, Meredith became extremely annoyed and terminated Sherlock's employment as editor of Better Homes and Gardens.

Meredith, who had been in and out of the office for months because of high blood pressure and overwork, and Fred Bohen, Meredith's son-in-law and the second in command in the company, began searching for a new editor for Better Homes and Gardens. Genevieve Callahan and Lou Richardson were placed in charge of the editorial operations temporarily, the first and only time women have ever held the reins over the editorial department of the magazine.

Sherlock went to Ladies' Home Journal as an associate editor the summer of 1927 and was its managing editor when he resigned in 1933. From that point his life was one of reverses. He lost money on 
the Marshalltown (Iowa) Marshalltonian and The Scratch Pad, a magazine he founded to criticize government policies, and in 1935 he was bankrupt and divorced. Sherlock was editor of the revived St. Nicholas magazine at the time of his suicide in 1938. Unfortunately, the man who first translated E. T. Meredith's idea for average American homemakers into a national magazine accepted by readers and advertisers alike experienced in his own life the antithesis of the message that Better Homes and Gardens expounded. 

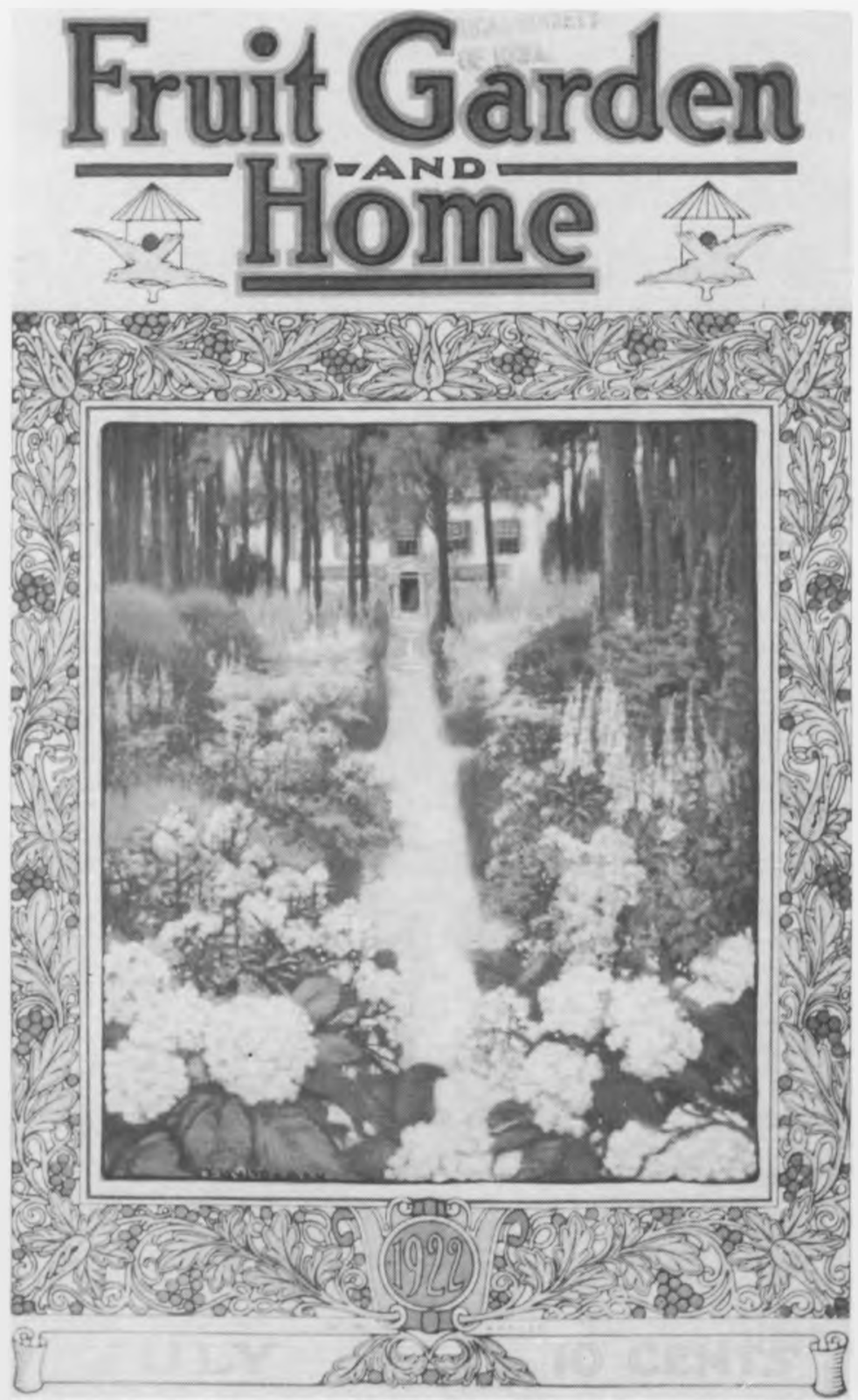

First issue, for July 1922, of Fruit, Garden and Home, edited by Chesla C. Sherlock. In 1924 this Des Moines-based magazine changed its name to Better Homes and Gardens. (Photo courtesy of the State Historical Society of Iowa.) 